\title{
Hubungan sosial ekonomi, pola asuh, pola makan dengan stunting pada siswa sekolah dasar di Kecamatan Lut Tawar, Kabupaten Aceh Tengah
}

\author{
Association between socio-economy, rearing pattern, eating pattern with stunting in elementary \\ school children in Lut Tawar Subdistrict, Centaral Aceh Regency
}

\author{
Basri Aramico', Toto Sudargo², Joko Susilo³
}

\begin{abstract}
Background: High prevalence of stunted children that indicates nutrition problem in Indonesia is a chronic problem associated with poverty, low education, and lack of service and environmental health. The low birth weight infant will have an impact on growth disorders in children.

Objectives: To identify association between social economic aspect of the family, rearing pattern, eating pattern and stunting in elementary school children in Lut Tawar Subditrict Central Aceh Regency.

Methods: The study were analytic observational with cross sectional design and qualitative method. Data were obtained through observation and interview using questionnaire. Samples were 378 children from 11 elementary school in Lut Tawar Subdistrict Central Aceh Regency. Samples were selected by proportional random sampling. Analysis used chi-square at confidence interval $95 \%$. Number of samples were 378 children.

Results: There were association between maternal education and nutritional status $(p<0.001) 0 R=4.06$; father education and nutritional status $(p<0.001) O R=3.37$; number of underfives with nutritional status $(p=0.007) O R=2.71$; income of parent and nutritional status $(p<0.001) O R=7.8$; rearing pattern and nutritional status $(p<0.001))$ OR=8.07; eating pattern and nutritional status $(p<0.001) O R=6.01$. There were dominant association between rearing pattern and nutritional status with $\mathrm{OR} 8$, between eating patern, income of parent and nutritional status with OR of 6.01 There were no association between acces and utilization of health service and nutritional status $(p=0,78)$ OR=0,93.

Conclusions: There were significant association between rearing pattern, eating pattern, and nutritional status.
\end{abstract}

KEYWORDS: stunting, rearing pattern, eating pattern

\begin{abstract}
ABSTRAK
Latar Belakang: Tingginya prevalensi anak pendek yang menunjukkan masalah gizi di Indonesia merupakan masalah kronis yang berkaitan dengan kemiskinan, rendahnya pendidikan, dan kurang memadainya pelayanan dan kesehatan lingkungan.

Tujuan: Untuk mengetahui hubungan antara aspek sosial ekonomi keluarga, pola asuh, pola makan, dan stunting pada anak sekolah dasar DI Kecamatan Lut Tawar Kabupaten Aceh Tengah. Metode: Penelitian observasional analitik menggunakan rancangan cross sectional dan metode kuantitatif, jumlah sampel 378 anak, yaitu siswa sekolah dasar kelas I-III pada 11 sekolah dasar. Sampel diambil berdasarkan proportional random sampling, pengumpulan data melalui wawancara dengan menggunakan kuesioner, pengolahan dan analisis data menggunakan program komputer yaitu analisis univariat, bivariat, dan multivariat.
\end{abstract}

\footnotetext{
1 Fakultas Ilmu Kesehatan Masyarakat, Universitas Muhammadiyah Aceh, Jalan Muhammadiyah No 91, Batoh, Lueng Bata, Banda Aceh 23245, e-mail: miko_data.eval@yahoo.com

${ }^{2}$ Prodi Gizi Kesehatan Fakultas Kedokteran Universitas Gadjah Mada, Jl. Farmako, Sekip Utara, Yogyakarta 55281, e-mail: totosud@ indosat.net.id

${ }^{3}$ Prodi Gizi Poltekkes Kemenkes Yogyakarta, Jl. Tata Bumi 3, Banyuraden, Gamping, Sleman, Yogyakarta 55293
} 
Hasil: Tidak ada hubungan antara jenis kelamin dengan status gizi $(p=0,39) O R=1,22$, tidak ada hubungan antara umur dengan status gizi $(p=0,25) O R=0,73$, tidak ada hubungan antara akses pelayanan kesehatan dengan status gizi $(p=0,78) O R=0,93$. Ada hubungan antara pendidikan ibu dengan status gizi $(p<0,001)$ $O R=4,06$, ada hubungan antara pendidikan ayah dengan status gizi $(p<0,001) O R=3,37$, ada hubungan antara jumlah balita dalam keluatga dengan status gizi $(p=0,007) O R=2,71$. Ada hubungan antara pendapatan orang tua dan status gizi $(p<0,001) O R=7,8$. Ada hubungan antara pola asuh dengan status gizi $(p<0,001)$ ) OR=8,07, ada hubungan antara pola makan dengan status gizi $(p<0,001)$ OR=6,01.

Kesimpulan: Ada hubungan yang signifikan antara pola asuh, penghasilan orang tua, pendidikan orang tua, dan pola makan dengan status gizi. Tidak ada hubungan antara jenis kelamin, umur dan akses pemanfaatan pelayanan kesehatan dengan status gizi.

KATA KUNCI: stunting, pola asuh, pola makan

\section{PENDAHULUAN}

Anak-anak pada masa usia sekolah dan remaja mengalami pertumbuhan baik mental, intelektual, fisik, dan sosial. Golongan umur ini perlu mendapatkan perhatian yang khusus. Oleh karena itu pemerintah mengeluarkan UU Kesehatan nomor 23 tahun 1992, khususnya pasal 17 untuk mewujudkan pertumbuhan dan perkembangan anak yang dimulai saat masa dalam kandungan, masa balita, usia pra sekolah, dan usia sekolah (1).

Masih tingginya prevalensi anak pendek yang menunjukkan masalah gizi di Indonesia merupakan masalah kronis yang berkaitan dengan kemiskinan, rendahnya pendidikan, serta kurang memadainya pelayanan dan kesehatan lingkungan. Masalah gizi oleh banyak faktor yang saling terikat secara langsung dapat dipengaruhi oleh penyakit infeksi dan kurangnya asupan gizi secara kualitas maupun kuantitas, sedangkan secara tidak langsung dipengaruhi oleh jangkauan dan kualitas pelayanan kesehatan, pola asuh anak yang kurang memadai, sanitasi lingkungan, serta rendahnya ketahanan pangan di tingkat rumah tangga (2). Tujuan penelitian ini adalah Untuk mengetahui hubungan antara aspek sosial ekonomi keluarga, pola asuh, pola makan, dan stunting pada anak sekolah dasar DI Kecamatan Lut Tawar Kabupaten Aceh Tengah.

\section{BAHAN DAN METODE}

Penelitian ini merupakan penelitian observasional analitik dengan rancangan cross sectional. Jumlah sampel pada penelitian ini adalah 378 anak, yaitu siswa sekolah dasar kelas I-III dari 11 sekolah dasar di wilayah Kecamatan Lut Tawar Kabupaten Aceh Tengah. Kriteria inklusi yaitu siswa kelas I-III, bersedia menjadi subjek penelitian dan diukur tinggi badan, serta bersedia menandatangani informed consent. Kriteria eksklusi yaitu anak yang menderita kelainan kongenital atau cacat fisik, anak yang sakit pada waktu penelitian, dan anak yang sedang dalam pengobatan penyakit infeksi. Variabel bebas yaitu status sosial ekonomi yang terdiri dari: pendidikan orang tua yang dikategorikan menjadi pendidikan tinggi (SMA, perguruan tinggi) dan pendidikan rendah (tidak sekolah, SD, SMP), penghasilan yang dikategorikan tinggi ( $\geq$ harga $20 \mathrm{~kg}$ beras/bulan/kapita) dan penghasilan yang dikategorikan rendah ( $\leq$ harga $20 \mathrm{~kg}$ beras/ bulan/ kapita). Sementara akses pelayanan kesehatan dikategorikan menjadi baik $\geq 14$ dan kurang baik $<14$. Akses pelayanan kesehatan yang dimaksud adalah akses keluarga dalam menerima informasi kesehatan dan pemanfaatan tempattempat pelayanan kesehatan yang ada dalam hal perawatan, penanganan masalah kesehatan keluarga terutama masalah kesehatan anak: rumah sakit, puskesmas, bidan, dan tenaga serta pelayanan kesehatan formal yang lain yang diperoleh melalui penghitungan rentang bilangan (median) dari jumlah skor pertanyaan. Pola makan dikategorikan cukup jika memenuhi $\geq 80 \%$ kebutuhan dan kurang jika memenuhi $<80 \%$ kebutuhan. Pola asuh diperoleh dari penghitungan rentang bilangan (median) dari jumlah skor pertanyaan. Hasil baik jika skor $\geq 72$ dan kurang jika <72). 
Data dan informasi dikumpulkan melalui wawancara dengan menggunakan kuesioner dan food frequency questionnaire. Data tinggi badan dan berat badan diukur dengan menggunakan microtoise dengan ketelitian $0,1 \mathrm{~cm}$ dan timbangan berat badan ketelitian $0,1 \mathrm{~kg}$. Selanjutnya data diolah dengan menggunakan software Nutrisurvey, data dan informasi yang terkumpul dianalisis secara bertahap melalui analisis bivariat dan multivariat dengan menggunakan uji statistik (uji chi-square). Penelitian ini telah memperoleh surat kelayakan etik dari Komisi Etik Penelitian Kedokteran dan Kesehatan Universitas Gadjah Mada dengan nomor Ref: KE/FK/594/EC tahun 2010.

\section{HASIL}

Deskripsi hubungan sosial ekonomi, pola asuh, pola makan dengan status gizi dapat dilihat pada Tabel 1.

\section{Hubungan jenis kelamin dengan status gizi}

Deskripsi hubungan jenis kelamin dengan status gizi pada Tabel 1 menunjukkan bahwa anak laki-laki yang berstatus gizi stunting adalah 74 $(31,8 \%)$ siswa dan status gizi normal $159(68,2 \%)$ siswa. Anak perempuan dengan status gizi stunting adalah $40(27,6 \%)$ dan normal 105 (72,4,\%). Hasil uji statistik diperoleh $p=0,39$ yang berarti tidak ada hubungan yang signifikan antara jenis kelamin dengan stunting.

\section{Hubungan umur dengan status gizi}

Tabel 1, menjelaskan bahwa pada rentang umur 8,1 hingga 11 tahun status gizi stunting sebanyak 24 (25,5\%). Rentang umur 5,1 hingga 8,0 tahun memiliki status gizi stunting dengan jumlah $90(31,7 \%)$ siswa. Hasil analisis antara kelompok umur dengan status gizi menunjukkan tidak ada hubungan yang signifikan $(p>0,05)$.

Tabel 1. Hubungan sosial ekonomi, pola makan, pola asuh dengan status gizi

\begin{tabular}{|c|c|c|c|c|c|c|c|}
\hline \multirow{2}{*}{ Variabel } & \multicolumn{2}{|c|}{ Stunting } & \multicolumn{2}{|c|}{ Normal } & \multirow{2}{*}{$c^{2}$} & \multirow[b]{2}{*}{$\mathbf{p}$} & \multirow{2}{*}{$\begin{array}{c}\text { OR } \\
(95 \% \mathrm{Cl})\end{array}$} \\
\hline & $\mathbf{n}$ & $\%$ & $\mathbf{n}$ & $\%$ & & & \\
\hline \multicolumn{8}{|l|}{ Jenis kelamin } \\
\hline Laki-laki & 74 & 31,8 & 159 & 68,2 & \multirow[t]{2}{*}{0,73} & \multirow{2}{*}{0,39} & 1,22 \\
\hline Perempuan & 40 & 27,6 & 105 & 72,4 & & & $0,77-1,92$ \\
\hline \multicolumn{8}{|l|}{ Umur (tahun) } \\
\hline $8,1-11,0$ & 24 & 25,5 & 70 & 74,5 & \multirow[t]{2}{*}{1,27} & \multirow[t]{2}{*}{0,26} & 0,73 \\
\hline $5,1-8,0$ & 90 & 31,7 & 194 & 68,3 & & & $0,43-1,25$ \\
\hline \multicolumn{8}{|l|}{ Pendidikan ibu } \\
\hline Rendah (tidak sekolah, SD, SMP) & 106 & 34,4 & 202 & 65,6 & \multirow{2}{*}{14,30} & \multirow{2}{*}{$0,000^{*}$} & 4,06 \\
\hline Tinggi (SMA, PT) & 8 & 11,4 & 62 & 88,6 & & & $1,87-8,80$ \\
\hline \multicolumn{8}{|l|}{ Pendidikan ayah } \\
\hline Rendah (tidak sekolah, SD, SMP) & 102 & 35,1 & 189 & 64,9 & \multirow[t]{2}{*}{14,37} & \multirow[t]{2}{*}{$0,000^{*}$} & 3,37 \\
\hline Tinggi (SMA, PT) & 12 & 13,8 & 75 & 86,2 & & & $1,75-6,45$ \\
\hline \multicolumn{8}{|l|}{ Akses dan pelayanan kesehatan } \\
\hline Kurang baik & 63 & 29,6 & 150 & 70,4 & \multirow[b]{2}{*}{0,08} & \multirow[b]{2}{*}{0,78} & 0,93 \\
\hline Baik & 51 & 30,9 & 114 & 69,1 & & & $0,60-1,46$ \\
\hline \multicolumn{8}{|l|}{ Jumlah balita yang diasuh } \\
\hline$>1$ (satu) & 16 & 51,6 & 15 & 48,4 & \multirow[t]{2}{*}{7,38} & \multirow[t]{2}{*}{0,007} & 2,71 \\
\hline 1 (satu) & 98 & 28,2 & 249 & 71,8 & & & $0,16-0,71$ \\
\hline \multicolumn{8}{|l|}{ Penghasilan orang tua } \\
\hline Rendah & 82 & 55,8 & 65 & 44,2 & \multirow[t]{2}{*}{74,98} & \multirow[t]{2}{*}{$0,000^{*}$} & 7,84 \\
\hline Tinggi & 32 & 13,9 & 199 & 86,1 & & & $4,78-12,87$ \\
\hline \multicolumn{8}{|l|}{ Pola asuh } \\
\hline Kurang baik & 88 & 53,0 & 78 & 47,0 & \multirow[t]{2}{*}{73,39} & \multirow[t]{2}{*}{$0,000^{*}$} & 8,07 \\
\hline Baik & 26 & 12,3 & 186 & 87,7 & & & $4,84-13,45$ \\
\hline \multicolumn{8}{|l|}{ Pola makan } \\
\hline Kurang & 44 & 63,8 & 25 & 36,2 & 45,26 & $0,000^{*}$ & 6,01 \\
\hline Cukup & 70 & 22,7 & 239 & 77,3 & & & $3,43-10,50$ \\
\hline
\end{tabular}

* Signifikan $(p<0,05)$ 


\section{Hubungan pendidikan orang tua dengan status gizi}

Deskripsi hubungan pendidikan orang tua dengan status gizi pada Tabel 1 menunjukkan bahwa pendidikan ibu yang rendah berisiko lebih besar pada kejadian stunting $(34,4 \%)$, dibandingkan dengan pendidikan ibu tinggi $(11, \%)$. Hasil uji statistik chi-square menunjukkan ada hubungan yang signifikan antara pendidikan ibu dengan status gizi $(p<0,05)$ dan odds ratio 4,06. Pendidikan ayah rendah berisiko 3,37 kali lebih besar menyebabkan status gizi sunting $(35,1 \%)$ dibandingkan dengan pendidikan ayah tinggi dengan status gizi stunting $(13,8 \%)$. Hasil uji statistik chi-square menunjukkan ada hubungan antara pendidkan ayah dengan status gizi $(p<0,05)$ dan odds ratio 3,37 .

\section{Hubungan akses dan pemanfaatan pelayanan kesehatan dengan status gizi}

Deskripsi hubungan akses dan pemanfaatan pelayanan kesehatan dengan status gizi pada Tabel 1 menunjukkan bahwa yang menyatakan akses dan pemanfaatan pelayanan kesehatan di Kecamatan Lut Tawar Kabupaten Aceh Tengah tergolong kurang baik $29,6 \%$, dan yang menyatakan pemanfaatan pelayanan kesehatan baik $(30,9 \%)$. Hasil tersebut menjelaskan bahwa akses dan pemanfaatan pelayanan kesehatan tidak berpengaruh terhadap kejadian stunting. Hasil uji statistik chi-square menunjukkan tidak ada hubungan yang signifikan antara akses dan pemanfaatan pelayanan kesehatan dengan status gizi $(p>0,05)$.

\section{Hubungan jumlah balita yang diasuh dalam keluarga dengan status gizi}

Tabel 1 menunjukkan bahwa jumlah balita yang diasuh dengan katagori kurang baik $(>1)$ berisiko 2,7 kali lebih besar menyebabkan status gizi stunting $(51,6 \%)$ dibandingkan dengan balita yang diasuh dengan kategori baik jumlah anak $=1$ status gizi stunting $(28,2 \%)$. Hasil uji statistik chi-square menunjukkan ada hubungan yang signifikan antara jumlah balita yang diasuh dalam keluarga dengan status gizi $(p<0,05)$ dan odds ratio 2,7 .
Hubungan penghasilan orang tua dengan status gizi

Deskripsi hubungan penghasilan orang tua dengan status gizi pada Tabel 1 menjelaskan bahwa penghasilan orang tua rendah berisiko 7,84 kali lebih besar menyebabkan stunting dibandingkan dengan penghasilan orang tua tinggi, masingmasing dengan status gizi stunting $55,8 \%$ dan $13,9 \%$. Hasil uji statistik chi-square menunjukkan ada hubungan yang signifikan antara penghasilan orang tua dengan status gizi $(p<0,001)$.

\section{Hubungan pola asuh dengan status gizi}

Deskripsi hubungan pola asuh dengan status gizi pada Tabel 1 menunjukkan bahwa kategori pola asuh kurang baik berisiko 8,07 kali lebih besar dibandingkan dengan pola asuh baik, masingmasing dengan persentase status gizi stunting $53 \%$ dan $12,3 \%$. Hasil uji statistik chi-square menunjukkan ada hubungan yang signifikan antara pola asuh dengan status gizi $(p<0,001)$.

\section{Hubungan pola makan dengan status gizi}

Deskripsi hubungan pola makan dengan status gizi pada Tabel 1, menunjukkan bahwa pola makan dengan kategori kurang berisiko 6,01 kali lebih besar menyebabkan status gizi stunting dibandingkan dengan pola makan dengan kategori cukup, masing-masing dengan status gizi stunting $63,8 \%$ dan $22,7 \%$. Hasil uji statistik chi-square menunjukkan ada hubungan yang signifikan antara pola makan dengan status gizi $(p<0,001)$.

\section{Analisis faktor risiko terhadap status gizi}

Hasil analisis faktor risiko hubungan antara sosial ekonomi, pola asuh, dan pola makan dengan status gizi dapat dilihat pada Tabel 2 .

Analisis multivariat hubungan antara sosial ekonomi, pola asuh ,dan pola makan dengan status gizi menjelaskan bahwa uji statistik variabel-variabel yang berpengaruh atau yang paling dominan mempengaruhi status gizi adalah pola asuh $(p<0,001)$ dengan odds ratio (OR) 8 , pola makan $(p<0,001)$ dan OR 6,22 , dan penghasilan orang tua $(p<0,000)$ dan OR 6,05. 
Tabel 2. Tabulasi hubungan sosial ekonomi, pola makan dan pola asuh dengan status gizi

\begin{tabular}{|c|c|c|c|}
\hline Variabel & SE & $\mathbf{p}$ & $\begin{array}{c}\text { OR } \\
(95 \% \mathrm{Cl})\end{array}$ \\
\hline Pendidikan ibu & 0,49 & 0,21 & $\begin{array}{c}1,85 \\
(0,70-4,85)\end{array}$ \\
\hline Pendidikan ayah & 0,44 & 0,74 & $\begin{array}{c}1,15 \\
(0,48-2,73)\end{array}$ \\
\hline Jumlah balita yang diasuh & 0,48 & 0,07 & $\begin{array}{c}2,33 \\
(0,91-5,98)\end{array}$ \\
\hline Penghasilan orang tua & 0,31 & 0,000 & $\begin{array}{c}6,05 \\
(3,24-11,29)\end{array}$ \\
\hline Pola asuh & 0,31 & 0,000 & $\begin{array}{c}8 \\
(4,3-14,62)\end{array}$ \\
\hline Pola makan & 0,37 & 0,000 & $\begin{array}{c}6,22 \\
(3-12,89) \\
\end{array}$ \\
\hline
\end{tabular}

\section{BAHASAN}

\section{Hubungan antara jenis kelamin, umur, dengan status gizi}

Hasil uji statistik hubungan antara jenis kelamin dengan status gizi diperoleh hasil $p=0,39$ yang menjelaskan tidak terdapat hubungan yang signifikan antara jenis kelamin dengan status gizi $(p<0,05)$. Hasil uji statistik antara umur dengan status gizi diperoleh hasil $p=0,26$ yang berarti bahwa tidak terdapat hubungan antara umur dengan status gizi $(p<0,05)$ pada Tabel 1.

Hasil penelitian ini sejalan dengan penelitian lain yang menjelaskan bahwa tidak terdapat hubungan yang signifikan antara anak laki-laki dan perempuan dengan kejadian kurang energi protein (KEP) pada balita dengan $p=0,36$, serta menjelaskan bahwa tidak terdapat hubungan yang signifikan antara kelompok umur dengan kejadian KEP dan hasil uji statistik menunjukkan bahwa nilai $p=0,58$ (3).

Hasil penelitian ini berbeda dengan penelitian sebelumnya, yang menjelaskan bahwa terdapat hubungan antara laki-laki dan perempuan dengan stunting pada siswa sekolah dasar dengan $p<0,001$ dengan OR laki-laki 0,76 dan perempuan 0,71. Penelitian ini juga menjelaskan bahwa sepertiga $(31,1 \%)$ dari anak laki-laki yang stunting berumur 12 tahun, dan anak perempuan yang stunting yaitu $(27,5 \%)$ berumur 11 tahun (4). Penelitian lainnya menjelaskan bahwa anak-anak yang berusia antara
10-14 tahun lebih berisiko menjadi stunting dengan OR sebesar 1,98 dibandingkan dengan anak di bawah usia 10-14 tahun yaitu pada usia 7-9 tahun. Selanjutnya penelitian ini juga menyebutkan bahwa tidak terdapat hubungan kekurangan asupan zat gizi antara anak laki-laki dan perempuan dengan $p=0,21(5)$.

Tingginya prevalensi bayi dengan berat badan lahir rendah (BBLR) dan gizi kurang pada balita akan berdampak pada gangguan pertumbuhan pada anak usia baru masuk sekolah. Hal ini merupakan indikasi gangguan kurang gizi kronis. Sebagai akibat lebih lanjut dari tingginya angka BBLR dan kurang gizi pada masa balita dan tidak adanya pencapaian perbaikan pertumbuhan (catch-up growth) yang sempurna pada masa berikutnya, pada usia sekolah banyak ditemukan anak yang kurang gizi. Prevalensi anak pendek ini semakin meningkat dengan bertambahnya umur dan gambaran ini ditemukan baik pada laki-laki maupun perempuan (2).

\section{Hubungan pendidikan orang tua dengan status gizi}

Hasil analisis uji statistik untuk pendidikan ibu dengan status gizi menunjukkan ada hubungan yang signifikan $(p=0,000)$ dan OR 4,06 . Hasil analisis uji statistik pendidikan ayah dengan status gizi menunjukkan ada hubungan yang signifikan antara pendidikan ayah dengan status gizi $(p<0,001)$ dan OR 3,37 seperti yang dijelaskan pada Tabel 1. Pendidikan orang tua yang tinggi dapat mengubah pola makan seseorang yang pada akhirnya berpengaruh terhadap status gizi keluarga termasuk anak.

Penelitian ini sejalan dengan penelitian yang menunjukkan hasil bahwa di antara anak-anak yang stunting, pendidikan ayah dan ibunya rendah dengan prevalensi $22,56 \%$ dan 23,26\%. Anak-anak yang tidak stunting memiliki pendidikan ayah dan ibu menengah ke atas dengan prevalensi $13,81 \%$ dan $12,53 \%$. Nilai OR sebesar 0,76 menunjukkan bahwa anak-anak dengan pendidikan ayah dan ibu rendah akan berisiko 0,76 kali lebih besar mengalami status gizi kurang (6).

Sementara penelitian lain juga menunjukkan hasil yang signifikan yaitu pendidikan orang tua 
mempengaruhi status gizi. Anak dengan pendidikan ayah dan ibu rendah akan mengalami kurang gizi atau stunting dengan rasio 20 kali lebih besar dibandingkan dengan anak dari orang tuanya yang berpendidikan tinggi (7).

Hasil penelitian lain yang mendukung penelitian ini menjelaskan bahwa terdapat hubungan antara pendidikan ibu dengan status gizi $(p<0,05$, $\mathrm{OR}=4,2,95 \% \mathrm{Cl}: 1,969-10,40)$. Hal ini menunjukkan bahwa anak yang ibunya memiliki pendidikan rendah memiliki risiko 4,2 kali mengalami gizi buruk dibandingkan dengan anak yang ibunya berpendidikan tinggi (8).

Pada penelitian lainnya ditemukan hubungan yang signifikan antara pendidikan ibu terhadap perkembangan anak dengan status gizi stunting ditinjau dari aspek personal social, motorik halus, bahasa, motorik kasar dengan hasil uji statistik $(p<0,05)$ dengan OR risiko menjadi stunting 2 kali lebih besar apabila ibu memiliki pendidikan rendah (9).

\section{Hubungan akses dan pemanfaatan pelayanan kesehatan dengan status gizi}

Hasil analisis uji statistik akses dan pemanfaatan pelayanan kesehatan dengan status gizi pada Tabel 1 tidak menunjukkan hubungan yang signifikan yaitu $(p=0,78)$. Pelayanan kesehatan merupakan faktor ketiga yang mempengaruhi derajat kesehatan masyarakat, karena keberadaan fasilitas pelayanan kesehatan sangat menentukan dalam pemulihan kesehatan, pencegahan terhadap penyakit, pengobatan, keperawatan, serta kelompok dan masyarakat yang memerlukan pelayanan kesehatan. Ketersedian fasilitas sangat dipengaruhi oleh lokasi yang dapat dijangkau oleh masyarakat atau tidak, tenaga kesehatan yang memberikan pelayanan, informasi, motivasi masyarakat untuk mendatangi fasilitas dalam memperoleh pelayanan, serta pelayanan kesehatan itu sendiri sesuai dengan kebutuhan masyarakat yang memerlukannya (10).

Hasil analisis uji statistik antara akses dan pemanfaatan pelayanan kesehatan dengan status gizi pada penelitian ini tidak menunjukkan hubungan yang signifikan $(p=0,78)$. Penelitian ini berbeda dengan penelitian sebelumnya yang menjelaskan bahwa pemanfaatan pelayanan polindes atau bidan dengan $z$-score indikator TB/ $U(p=0,020)$. $\mathrm{Hal}$ ini menunjukkan ada hubungan antara akses pelayanan kesehatan dengan status gizi TB/U. Jarak sarana pelayanan kesehatan terdekat mempunyai korelasi positif dengan dengan $z$-score indikator $B B / T B(p=0,010)$, yang juga menjelaskan bahwa ada hubungan yang singnifikan antara jarak sarana pelayanan kesehatan dengan status gizi (11).

Penelitian ini juga menunjukkan hasil yang berbeda dengan penelitian sebelumnya, yang menjelaskan bahwa proporsi gizi buruk pada anak balita lebih banyak ditemukan pada akses pelayanan kesehatan yang kurang baik dibandingkan dengan akses pelayanan kesehatan yang baik dan memiliki hubungan yang bermakna yaitu dengan kali anak dengan pelayanan kesehatan kurang baik berisiko 10,2 kali lebih besar menyebabkan gizi buruk (7).

\section{Hubungan jumlah balita yang diasuh dalam keluarga dengan status gizi}

Hasil analisis uji statistik menunjukkan hubungan yang signifikan antara jumlah balita yang diasuh dalam keluarga dengan status gizi $(p=0,007)$ dan OR 2,71(Tabel 1). Hasil penelitian ini berbeda dengan penelitian sebelumnya yang menunjukkan tidak ada hubungan antara jumlah anak dengan pola makan. Jumlah anak dari ibu $\leq 2$ memiliki pola asuh makan baik namun hasil uji statistik penelitian tersebut tidak menunjukkan hubungan dengan status gizinya $(p=0,49)(11)$.

Penelitian lain yang berbeda dengan penelitian ini juga menjelaskan bahwa tidak ada hubungan antara jumlah balita $(<2)$ dalam keluarga dengan status gizi kurangan energi protein (KEP). Hasil uji statistik penelitian tersebut menunjukkan nilai $p=0,23$ yang berarti tidak ada perbedaan antara yang kurang energi protein dan tidak kurang energi protein jika dikaitkan dengan jumlah balita yang diasuh dalam satu keluarga (3).

Hasil ini sejalan dengan penelitian yang menjelaskan bahwa jarak kelahiran anak yang kurang dari 5 tahun menunjukkan hubungan yang signifikan dengan status gizi stunting $(p=0,04)$, sedangkan jarak kelahiran lebih dari dua tahun tidak 
menunjukkan hubungan yang signifikan dengan status gizi stunting $(p=0,78)$. Hasil penelitian tersebut juga menunjukkan bahwa jumlah balita yang diasuh dalam keluarga kurang dari satu dapat mempengaruhi status gizi stunting, sedangkan yang lebih dari 1 tidak menunjukkan hubungan yang signifikan dengan status gizi stunting (12). Jarak usia balita yang ada dalam satu keluarga minimal 3 tahun. Semakin sedikit balita yang diasuh, maka kebutuhan anak baik ekonomi atau kebutuhan lainnya untuk tumbuh kembang akan lebih terpenuhi (13).

\section{Hubungan penghasilan orang tua dengan status gizi}

Hasil analisis menunjukkan ada hubungan antara penghasilan orang tua dengan status gizi dengan ( $p<0,001)$ dan OR 7,84 (Tabel 1). Pada penelitian lain yang sejalan dengan penelitian ini menjelaskan bahwa sosial ekonomi orang tua sangat berpengaruh terhadap status gizi, sedangkan ketimpangan sosial ekonomi berdasarkan pendapatan per kapita atau penghasilan berbasis aset rumah tangga menunjukkan relatif mempengaruhi status gizi (stunting). Rasio penurunan status gizi stunting apabila sosial ekonomi tinggi pada tahun 1974-1975 yaitu 4,9 dan rasio status gizi stunting meningkat apabila status ekonomi rendah menjadi 7,7 pada tahun 1989, kemudian rasio status gizi stunting menurun tajam menjadi 2,6 apabila status ekonomi tinggi pada tahun 2006-2007. Hasil dari penurunan ini menunjukkan bahwa sosial ekonomi rendah menunjukkan status gizi yang kurang baik, dan sosial ekonomi tinggi menunjukkan status gizi yang baik (12).

Penelitian ini juga sejalan dengan penelitian sebelumnya yang menunjukkan hubungan yang signifikan dengan status gizi $(p<0,05)$. Nilai $O R=3,5$ 95\% Cl: 1,178-10,176 (>1) menunjukkan bahwa keluarga dengan status ekonomi rendah memiliki peluang anaknya untuk menderita gizi buruk 3,5 kali lebih besar dibandingkan dengan keluarga yang berstatus ekonomi tinggi. Penelitian lain yang sejalan menjelaskan bahwa status sosial ekonomi (aset rumah tangga) responden yang rendah berisiko 21 kali lebih besar menyebabkan stunting dibandingkan dengan yang memiliki sosial ekonomi tinggi (7). Pada penelitian di Jamaica menjelaskan bahwa anak-anak yang stunting mengalami gangguan lebih banyak dalam melaksanakan aktivitas sehari-hari dibandingkan dengan anakanak yang tidak stunting. Anak-anak yang stunting tersebut berasal dari keluarga dengan status sosial ekonomi yang rendah (14).

Secara umum, dapat dikatakan bahwa antara peningkatan ekonomi dan peningkatan status gizi memiliki hubungan timbal balik. Hal tersebut dapat dilihat dari dua sisi, pertama berkurangya biaya berkaitan dengan kematian dan kesakitan akibat kekurangan gizi, dan dari sisi lain akan meningkatkan produktivitas. Manfaat ekonomi yang diperoleh sebagai dampak dari perbaikan status gizi adalah berkurangnya kematian bayi dan anak balita, berkurangnya biaya perawatan untuk neonatus bayi dan balita, produktivitas meningkat karena berkurangnya anak yang menderita kurang gizi dan adanya kemampuan peningkatan intelektualitas, berkurangnya biaya karena penyakit kronis, serta meningkatnya manfaat intelektualitas melalui peningkatan kualitas kesehatan (15).

\section{Hubungan pola asuh dengan status gizi}

Hasil uji statistik chi-square menunjukkan ada hubungan yang signifikan antara pola asuh dengan status gizi $(p<0,001)$ dengan OR 8,07 . Hal ini menunjukkan bahwa subjek penelitian dengan pola asuh yang kurang baik memiliki risiko menjadi stunting 8 kali lebih besar dibandingkan dengan subjek penelitian dengan pola asuh yang baik.

Hasil penelitian sebelumnya menjelaskan hasil yang berbeda dengan penelitian ini, yaitu menunjukkan tidak adanya hubungan yang signifikan antara pola asuh yang baik dan yang kurang baik dengan status gizi $(p=0,533)(11)$. Sementara hasil penelitian sebelumnya yang sejalan dengan penelitian menunjukkan hubungan yang signifikan antara pola asuh dengan KEP $(p<0,001)$ dan OR 9,47 yang artinya anak dengan pola asuh kurang baik berisiko 9,47 kali lebih besar mengalami kekurangan protein (3).

Penelitian lain yang sejalan dengan penelitian ini yaitu tentang pengaruh faktor psikologis perhatian ibu dan perawatan anak. Hasil yang diperoleh dari menunjukkan hubungan yang signifikan antara 
pola asuh dan perawatan ibu dengan status gizi (6). Penelitian ini juga didukung oleh hasil penelitian lainnya yang menjelaskan bahwa ada hubungan yang signifikan antara balita KEP dengan yang tidak KEP. Kurangnya pengetahuan ibu dalam mengasuh balita akan berdampak pada status gizi balita tersebut. Hasil penelitian ini menjelaskan bahwa pengasuhan ibu yang kurang baik dapat menyebabkan anak KEP 6 kali lebih besar dibandingkan dengan pengasuhan ibu yang baik. Selanjutnya, sikap ibu yang kurang baik dalam mengasuh balita dapat menyebabkan risiko KEP 4 kali lebih besar dibandingkan dengan sikap pengasuhan ibu yang baik. Praktik ibu dalam mengasuh yang kurang baik berisiko 3 kali lebih besar menyebabkan balita KEP pada anak dibandingkan dengan praktik ibu yang baik (3).

Hasil penelitian lain menemukan bahwa ada hubungan antara anak usia dini dan faktor psikologis. Pola asuh di dalam maupun di luar keluarga yang kurang baik menyebabkan stunting pada anak usia sekolah (16). Berdasarkan penelitian lainnya, secara keseluruhan dapat disimpulkan bahwa pengasuhan ibu yang kurang baik terhadap anak akan berisiko 9 kali lebih besar menyebabkan KEP pada balita dibandingkan dengan ibu yang mempunyai praktik pengasuhan balita yang baik (3).

Kebutuhan fisik biomedis (asuh) meliputi pangan dan gizi merupakan kebutuhan terpenting. Kebutuhan dan perawatan kesehatan dasar yang terpenting bagi anak di antaranya: imunisasi, pemberian ASI, penimbangan bayi/anak dan pengobatan jika sakit, papan/pemukiman yang layak, higiene perorangan, sanitasi lingkungan yang baik, sandang dan kesegaran jasmani. Stimulasi mental merupakan cikal bakal dalam proses belajar (pendidikan dan pelatihan) pada anak. Stimulasi mental (asah) ini mengembangkan perkembangan mental psikososial, kecerdasan, keterampilan, kemandirian, kreativitas, agama, kepribadian, moral etika, dan produktivitas (17).

\section{Hubungan pola makan dengan status gizi}

Hasil analisis uji statistik hubungan antara pola makan dengan status gizi menunjukkan hubungan yang signifikan $(p<0,001)$ dan OR 6,01. Penelitian ini sejalan dengan penelitian sebelumnya yang menjelaskan ada hubungan antara pola makan dan status gizi stunting $(p=0,040)$ dan OR 3,3. Hasil tersebut menjelaskan bahwa anak dengan pola makan kurang berisiko 3 kali lebih tinggi untuk menjadi stunting (18). Penelitian di Brazil membuktikan bahwa anak dengan pola makan kurang atau mengonsumsi asupan protein di bawah rata-rata kecukupan gizi per hari, berisiko 1,5 kali lebih besar mengalami stunting $(p=0,004)$. Dari penelitian ini juga diketahui bahwa anak dengan asupan lemak di bawah rata-rata konsumsi per hari berisiko $2(1,98)$ kali lebih besar mengalami stunting $(p<0,001)(5)$. Sementara pada penelitian di Amerika Latin menjelaskan bahwa hubungan antara kekurangan gizi dan yang tidak kurang gizi mengalami perubahan yang cepat pada pola makan dan kegiatan fisik pada anak sekolah (14).

Pada penelitian di Mesir menjelaskan bahwa kondisi sosial ekonomi berpengaruh pada pola asupan makan atau gizi anak, selain itu faktor genetik harus diperhatikan. Ada dua studi yang menyebutkan peran antara karakteristik genetik dengan status gizi. Walau demikian, pemeriksaan genetik tidak terbukti mempengaruhi stunting, namun konstribusinya bagi penelitian status gizi penting untuk dikaji (19).

Keadaan status gizi atau stunting pada anak usia sekolah disebabkan oleh pola asupan makan yang kurang seperti protein, dan lemak yang dapat menyebabkan tingginya prevalensi stunting yaitu $(22,1 \%)(5)$.

\section{Faktor risiko terhadap status gizi}

Hasil analisis multivariat pada Tabel 2 menunjukkan bahwa variabel independent yang dominan dalam mempengaruhi status gizi adalah pola asuh, pola makan, dan penghasilan orang tua. Pada penelitian sebelumnya menjelaskan bahwa praktik ibu dalam pengasuhan balita yang kurang baik lebih banyak pada balita KEP dibandingkan dengan balita yang tidak KEP. Pola pengasuhan ibu dalam pengasuhan anak yang kurang baik secara keseluruhan mempunyai peluang 9 kali lebih besar menyebabkan balita KEP dibandingkan dengan ibu yang mempunyai praktik pengasuhan balita yang baik (3). 


\section{KESIMPULAN DAN SARAN}

Pada penelitian ini ditemukan hubungan antara sosial ekonomi, pola asuh, dan pola makan dengan stunting. Faktor dominan yang mempengaruhi stunting yaitu pola asuh, pola makan, penghasilan orang tua, akses dan pemanfaatan pelayanan kesehatan tidak memiliki hubungan yang signifikan dengan stunting.

Berdasarkan hasil penelitian di atas, saran yang diberikan yaitu bagi instansi terkait di bidang kesehatan diharapkan dapat menjalankan atau meningkat program yang berhubungan dengan peningkatan status gizi pada anak sekolah, terutama pada anak balita, sosialisasi pemberian makanan tambahan, cara mengasuh dan merawat anak melalui penyuluhan, pendidikan kesehatan langsung ke masyarakat dan melaksanakan promosi kesehatan tentang makanan seimbang bagi anak-anak dan balita agar ibu, keluarga, pengasuh dapat mengetahui kebutuhan asupan makan yang diperlukan oleh balita dan anak-anak.

\section{RUJUKAN}

1. Handari SRTH S. Perbedaan status gizi siswa sekolah dasar di dua sekolah berdasarkan status sosial ekonomi di Jakarta Selatan tahun 2004. J Kedokt dan Kesehat. 2005;1(2):157-65.

2. Hadi H. Beban ganda masalah gizi dan implikasinya terhadap kebijakan pembangunan kesehatan. Yogyakarta; 2005.

3. Razak A, Gunawan I, Budiningsari R. Pola asuh ibu sebagai faktor risiko kejadian kurang energi protein (KEP) pada anak balita. J Gizi Klin Indones. 2009;6(2):95-103.

4. Al-Saffar A. Stunting among primary-school children: a sample from Baghdad,Iraq. East Mediterr Heal J. 2009;15(2):322-9.

5. Assis A, Prado M, Barreto M, Reis M, Pinheiro, Concecau $S$, et al. Childhood stunting in Northeast Brazil: the role of schistosoma mansoni infection and inadequate dietary intake. Eur J Clin Nutr. 2004;58:1022-9.

6. Ramli, Agho K, Inder K, Bowe S, Jacobs J, Dibley M. Prevalence and risk factors for stunting and severe stunting among under-five in North Maluku Province of Indonesia. BMC Pediatr. 2009;9(64):1-10.

7. Faiza E. Faktor kejadian gizi buruk pada anak balita (12-59 Bulan) di wilayah kerja Puskesmas Andalas Kecamatan Padang Timur Kota pada tahun 2007. J Media Gizi Kel. 2007;31(1):80-8.

8. Hizni A, Julia M, Gumayanti I. Status stunted dan hubungannya dengan perkembangan di wilayah Pesisir Pantai Utara Kecamatan Lemahwungkuk Kota Cirebon. J Gizi Klin Indones. 2010;6(3):131-7.

9. Azwar. Kecenderungan masalah gizi dan tantangan di masa datang. Disampaikan pada Pertemuan Advokasi Program Perbaikan Gizi Menuju Keluarga Sadar Gizi. 2004.

10. Khaldun. Z-Score status gizi balita di Provinsi Sulawesi Selatan 2007. J Sains Teknol. 2007;8(2):112-25.

11. Prasetyo B, Prawirohartono ER. Hubungan kelahiran dan jumlah anak dengan status gizi anak taman kanak-kanak. J Gizi Klin Indones. 2008;4(3):133-9.

12. Monteiro C, Benicio MD, Conde W, Konno S, Lavadino A, Barros A, et al. Narrowing socioeconomic inequality in child stunting: the Brazilian experience, 1974-2007. Bull World Heal Organ. 2010;88:305-11.

13. Walker S, Chang S, Powell C, Somonoff E, McGregor M. Early childhood stunting is associated with poor psychological functioning in late adolescence and effects are reduced by psychosocial stimulation. Am Soc Nutr. 2007;137(11):2464-9.

14. Duran $P$, Cabalero B, De Onis M. The association between stunting and overweight in Latin American and Caribbean Preschool Children. Food Nutr Bull. 2006;27(4):300-6.

15. Ngatsiah. Perawatan anak sakit. Jakarta: Buku Kedokteran EGC; 2005.

16. Asrar M, Hadi H, Buediman D. Pola asuh, pola makan, asupan zat gizi dan hubungannya dengan status gizi anak balita Masyarakat Nuaulu di Kecamatan Amahai Kabupaten Maluku Tengah Provinsi Maluku. J Gizi Klin Indones. 2009;6(2):84-94. 
17. Soetjiningsih. Tumbuh kembang anak. Jakarta: Buku Kedokteran EGC; 1995.

18. Murage K, Pettifor, Tilman, Dnger, Norris O\&. The prevelence of stunting, over weight and obesity and metabolic desease risk in Rural
South African Children. Bio Med Cent Public Heal. 2010;10(158):3-13.

19. Zottarelli L, Sunil T, Rajaram S. Influence of parental and socioeconomic factors on stunting in children under 5 years in Egypt. East Mediterr Heal J. 2007;13(6):1330-42. 